\title{
TTP as a surrogate endpoint in advanced hepatocellular carcinoma treated with molecular targeted therapy: meta-analysis of randomised controlled trials
}

\author{
Dae-Won Lee ${ }^{1}$, Myoung-Jin Jang ${ }^{2}$, Kyung-Hun Lee ${ }^{\star, 1,3}$, Eun Ju Cho ${ }^{1,4}$, Jeong-Hoon Lee ${ }^{1,4}$, Su Jong Yu J $^{1,4}$, \\ Yoon Jun Kim ${ }^{1,4}$, Jung-Hwan Yoon ${ }^{1,4}$, Tae-Yong Kim ${ }^{1,3}$, Sae-Won Han ${ }^{1,3}$, Do-Youn Oh ${ }^{1,3}$, Seock-Ah Im $^{1,3}$ \\ and Tae-You Kim ${ }^{1,3}$ \\ ${ }^{1}$ Department of Internal Medicine, Seoul National University Hospital, Seoul, South Korea; ${ }^{2}$ Medical Research Collaborating \\ Center, Seoul National University Hospital, Seoul, South Korea; ${ }^{3}$ Cancer Research Institute, Seoul National University College of \\ Medicine, Seoul, South Korea and ${ }^{4}$ Liver Research Institute, Seoul National University College of Medicine, Seoul, South Korea
}

Background: Time to progression (TTP) is suggested as a reliable endpoint compared with the progression-free survival in the clinical trials of hepatocellular carcinoma (HCC). However, the correlation between TTP and overall survival (OS) has never been studied.

Methods: We searched PubMed and Embase data to obtain data source. Eligible studies were randomised controlled phase III trials, which evaluated the efficacy of systemic chemotherapy or molecular targeted therapy in advanced HCC. The association of treatment effects as shown by the hazard ratio (HR) of TTP and OS in each trial was assessed by the Spearman rank correlation coefficient $\left(r_{\mathrm{s}}\right)$ and linear regression analysis. The association between median TTP and OS was also investigated.

Results: Nine studies with a total of 18 treatment arms and 6318 patients were included. Incremental benefit from the study treatment in TTP from each trial was correlated with incremental benefit in OS. The $r_{s}$ value and $R^{2}$ value between log $\left(H R_{T T P}\right)$ and $\log \left(\mathrm{HR}_{\mathrm{OS}}\right)$ was $0.73(95 \%$ confidence interval $(\mathrm{Cl}) 0.12-0.94, P=0.024)$ and 0.57 . The minimum TTP effect to predict a treatment effect on OS was 0.63. Median TTP was associated with median OS. The $r_{\mathrm{s}}$ value between TTP and OS was 0.73 (95\% $\mathrm{Cl} 0.40-0.89$, $P<0.001)$ and the corresponding $R^{2}$ was 0.42 .

Conclusions: Our study results suggest that TTP could be used as a surrogate marker for OS in the clinical trials of advanced HCC. However, the results suggest modest correlation between treatment effects on TTP and OS.

In 2012, an estimated 782500 new cases and 745000 deaths by liver cancer occurred worldwide (Torre et al, 2015). The incidence of liver cancer among all cancer is fifth and ninth in men and women, respectively (Torre et al, 2015). Most primary liver cancers occurring worldwide are hepatocellular carcinoma (HCC) (Torre et al, 2015). Compared with the low incidence of liver cancer, mortality of liver cancer is relatively high. Liver cancer is the second leading cause of cancer death in men and sixth common cause of cancer death in women (Torre et al, 2015). The prognosis of HCC is poor as considerable numbers of patients with HCC is diagnosed at advanced stages and have concurrent liver failure (Thomas et al, 2010).

HCC is highly refractory to conventional systemic chemotherapy (Zhu, 2006). In advanced disease, molecular targeted agent

*Correspondence: Dr K-H Lee; E-mail: kyunghunlee@snu.ac.kr

Received 10 July 2016; revised 1 September 2016; accepted 7 September 2016; published online 13 October 2016

(c) 2016 Cancer Research UK. All rights reserved 0007 - 0920/16 
sorafenib has shown efficacy and is the current standard of care (Llovet et al, 2008b; Cheng et al, 2009). Recently, a number of studies investigated the efficacy of novel molecular targeted agents such as sunitinib, everolimus, brivanib, linifanib, and ramucirumab in advanced HCC (Cheng et al, 2013; Johnson et al, 2013; Llovet et al, 2013; Zhu et al, 2014, 2015a, b; Cainap et al, 2015). However, all study results turned out to be negative in both first line and second line settings. Recently, regorafenib has shown efficacy in HCC patients who progressed on sorafenib (Bruix et al, 2016). At present, sorafenib is the only systemic agent approved for advanced HCC and regorafenib may be an option after failure of sorafenib.

Overall survival (OS) is the most important endpoint in oncology clinical trials. However, OS can be affected by sequential treatments and requires longer follow-up duration compared with the surrogate endpoints. Using surrogate endpoints may facilitate earlier analysis of study data and provide more direct measure of study efficacy, eliminating the impact of sequential treatments. Progression-free survival (PFS) and disease-free survival is suggested as an appropriate surrogate endpoint in phase II or III clinical trial conducted in solid tumour patients. The correlation between surrogate endpoints and OS has been validated in many types of cancer, including breast cancer, colorectal cancer, and lung cancer (Buyse et al, 2000b, 2007, 2009; Sargent et al, 2005; Petrelli and Barni, 2014; Blumenthal et al, 2015; Ozer-Stillman et al, 2015). However, there is no study that has evaluated the correlation between surrogate endpoints and OS in advanced HCC.

Many trials are being carried out to better understand the molecular pathogenesis of HCC and to develop novel treatments for HCC. However, the design of clinical trials of HCC is difficult as it is a heterogeneous disease in terms of aetiology. The leading cause of HCC in Asia and Africa is hepatitis B virus (HBV) compared with hepatitis C virus (HCV) in Europe and North America (Bosch et al, 1999). Non-viral causes such as alcoholic cirrhosis and many inherited metabolism disease (Wilson's disease, hemochromatosis, etc.) can also develop HCC (Fattovich et al, 2004). Heterogeneous population included in the HCC clinical trial can confound the study results. In addition, many patients with HCC have concurrent liver failure (Llovet et al, 2008a). As death resulting from liver failure can confound the potential benefits of effective drug, time to progression (TTP) has been suggested as a reliable surrogate endpoints in HCC compared with PFS (Llovet et al, 2008a). However, there is no evidence whether TTP is a reliable surrogate marker in HCC.

The primary purpose of this study was to evaluate the relationship between TTP and OS in advanced HCC.

\section{MATERIALS AND METHODS}

Literature review, selection criteria and data extraction. Randomised controlled phase III clinical trials of HCC that evaluated the efficacy of systemic chemotherapy or molecular targeted therapy were identified through PubMed and Embase. Two authors (DWL and KHL) independently carried out a comprehensive systemic search. The main keywords used for the search were 'hepatocellular carcinoma', 'advanced or metastatic' and 'randomized controlled trial'. Article published from January 1, 2008 through July 1, 2015 were included. Eligibility criteria for the included studies were: randomised controlled phase III trials, studies involving patients with advanced HCC and studies evaluating the role of systemic chemotherapy or molecular targeted agent, studies with TTP data. When duplicate publications were identified, we included the most recent article. Studies assessing the efficacy of systemic therapies in combination to loco-regional therapies were excluded.
For each included study, two authors (DWL and KHL) abstracted data for study design, study phase, study period, institution, main inclusion and exclusion criteria, treatment regimen, line of treatment, sample size per treatment arm, baseline characteristics of study patients and data on TTP and OS. All data and analyses were based on all randomly assigned patients using the intention-to-treat approach. Survival data (PFS, TTP and OS) were collected in median data for each trial arms. Hazard ratios (HRs) of control to experimental arm for these endpoints were extracted. When available, confidence intervals (CI) were also collected to evaluate the variations in median outcome.

Statistical analysis. The primary objective of this study was to investigate whether TTP could be used as a surrogate marker for OS in advanced HCC patients treated with systemic chemotherapy or molecular targeted therapy. Subgroup analysis was planned to compare the surrogate role of TTP in first line therapy and second line therapy.

The correlation between HR of TTP and HR of OS and the correlation between median TTP and median OS were evaluated using spearman rank correlation coefficient $\left(r_{\mathrm{s}}\right.$ or rho). Weighted linear regression analysis was also performed to investigate the correlation between these endpoints and to measure the percentage of OS accounted for by TTP (coefficient of determination, $R^{2}$ ). To account for the difference in sample sizes between arms and studies, data were weighted by the number of patients in linear regression analysis.

The correlation between treatment effects on TTP and OS was evaluated based on the $\log \left(\mathrm{HR}_{\mathrm{TTP}}\right)$ and $\log \left(\mathrm{HR}_{\mathrm{OS}}\right)$. A linear regression line with $95 \%$ CI was used to predict the treatment effects on OS from the observed treatment effects on TTP. Twosided $P$-values of $<0.05$ were considered statistically significant. Statistical analysis was performed with the software package (SAS, version 9.2; SAS Institute, Cary, NC, USA).

\section{RESULTS}

Study characteristics. Following the systematic literature review, a total of 9 trials were identified with 18 treatment arms and a total of 6318 patients (Table 1). All studies were phase III trials and evaluated the efficacy of molecular targeted agent. Six studies were performed in systemic chemotherapy naive patients and three studies were conducted in patients who failed sorafenib treatment (Llovet et al, 2013; Zhu et al, 2014, 2015a). The median TTP and OS of each treatment arm ranged from 1.4 to 5.5 months and 4.2 to 10.7 months, respectively.

Most patients in the included studies had Eastern Cooperative Oncology Group performance status 0-1, Barcelona Clinic Liver Cancer stage B-C and child-Pugh score A-B (Table 2). However, the aetiology of HCC was heterogeneous that $18-93 \%$ had HBV, $4-30 \%$ had HCV and $12-27 \%$ had alcoholic liver failure.

TTP as a surrogate marker for OS. All nine studies reported TTP and three studies reported PFS. Correlation between TTP and OS was analysed using the Spearman rank correlation coefficient. Median OS was associated with median TTP and the $r_{\mathrm{s}}$ values between TTP and OS were 0.73 (95\% CI $0.40-0.89, P<0.001$ ). Using linear regression weighted by sample sizes, $R^{2}$ value was 0.41 (95\% CI 0.06-0.64, $P=0.004$ ) and the correlation between OS and TTP was 'OS $=5.59+0.87$ TTP' (Figure 1 ).

Although TTP can be used as a surrogate marker, their power of predicting OS can be confounded by following treatments. In this analysis, 12 treatment arms from 6 studies was conducted in treatment naïve population and 6 treatment arms in 3 studies evaluated second line treatment. We investigated the association between TTP and OS according to the treatment line. The $r_{\mathrm{s}}$ values between TTP and OS was 0.59 (95\% CI 0.02-0.87, $P=0.043)$ and 


\begin{tabular}{|c|c|c|c|c|c|c|c|c|c|}
\hline References & Treatment arms & $N$ & Line & Arms ID & Endpoints & Median TTP & Median OS & HR TTP & HR OS \\
\hline Llovet et al (2008b) & $\begin{array}{l}\text { Sorafenib } \\
\text { Placebo }\end{array}$ & $\begin{array}{l}299 \\
303\end{array}$ & 1st & $\begin{array}{l}1 a \\
1 b\end{array}$ & $\begin{array}{l}\text { TTP } \\
\text { TTP }\end{array}$ & $\begin{array}{l}5.5(4.1-6.9) \\
2.8(2.7-3.9)\end{array}$ & $\begin{array}{c}10.7(9.4-13.3) \\
7.9(6.8-9.1)\end{array}$ & $\begin{array}{c}0.58 \\
(0.45-0.74)\end{array}$ & $\begin{array}{c}0.69 \\
(0.55-0.87)\end{array}$ \\
\hline Cheng et al (2009) & $\begin{array}{l}\text { Sorafenib } \\
\text { Placebo }\end{array}$ & $\begin{array}{r}150 \\
76\end{array}$ & 1st & $\begin{array}{l}2 a \\
2 b\end{array}$ & $\begin{array}{l}\text { TTP } \\
\text { TTP }\end{array}$ & $\begin{array}{l}2.8(2.6-3.6) \\
1.4(1.4-1.6)\end{array}$ & $\begin{array}{l}6.5(5.6-7.6) \\
4.2(3.8-5.5)\end{array}$ & $\begin{array}{c}0.57 \\
(0.42-0.79)\end{array}$ & $\begin{array}{c}0.68 \\
(0.50-0.93)\end{array}$ \\
\hline Llovet et al (2013) & $\begin{array}{l}\text { Brivanib } \\
\text { Placebo }\end{array}$ & $\begin{array}{l}263 \\
132\end{array}$ & 2nd & $\begin{array}{l}3 a \\
3 b\end{array}$ & $\begin{array}{l}\text { TTP } \\
\text { TTP }\end{array}$ & $\begin{array}{l}4.2 \\
2.7\end{array}$ & $\begin{array}{l}9.4 \\
8.2\end{array}$ & $\begin{array}{c}0.56 \\
(0.42-0.76)\end{array}$ & $\begin{array}{c}0.89 \\
(0.69-1.15)\end{array}$ \\
\hline Johnson et al (2013) & $\begin{array}{l}\text { Brivanib } \\
\text { Sorafenib }\end{array}$ & $\begin{array}{l}577 \\
578\end{array}$ & 1st & $\begin{array}{l}4 a \\
4 b\end{array}$ & $\begin{array}{l}\text { TTP } \\
\text { TTP }\end{array}$ & $\begin{array}{l}4.2(4.1-4.3) \\
4.1(3.1-4.2)\end{array}$ & $\begin{array}{l}9.5(8.3-10.6) \\
9.9(8.5-11.5)\end{array}$ & $\begin{array}{c}1.01 \\
(0.88-1.16)\end{array}$ & $\begin{array}{c}1.07 \\
(0.94-1.23)\end{array}$ \\
\hline Cheng et al (2013) & $\begin{array}{l}\text { Sunitinib } \\
\text { Sorafenib } \\
\text { Sunitinib } \\
\text { Sorafenib }\end{array}$ & $\begin{array}{l}530 \\
544\end{array}$ & 1 st & $\begin{array}{l}5 a \\
5 b\end{array}$ & $\begin{array}{l}\text { TTP } \\
\text { TTP } \\
\text { PFS } \\
\text { PFS }\end{array}$ & $\begin{array}{l}4.1(3.2-4.1) \\
3.8(2.9-4.2) \\
3.6(2.8-4.1) \\
3.0(2.8-4.0)\end{array}$ & $\begin{aligned} 7.9 & (7.4-9.2) \\
10.2 & (8.9-11.4) \\
7.9 & (7.4-9.2) \\
10.2 & (8.9-11.4)\end{aligned}$ & $\begin{array}{c}1.13 \\
(0.98-1.31) \\
1.13 \\
(0.99-1.30)\end{array}$ & $\begin{array}{c}1.30 \\
(1.13-1.50) \\
1.30 \\
(1.13-1.50)\end{array}$ \\
\hline Zhu et al (2014) & $\begin{array}{l}\text { Everolimus } \\
\text { Placebo }\end{array}$ & $\begin{array}{l}362 \\
184\end{array}$ & 2nd & $\begin{array}{l}6 a \\
6 b\end{array}$ & $\begin{array}{l}\text { TTP } \\
\text { TTP }\end{array}$ & $\begin{array}{l}3.0(2.8-4.0) \\
2.6(1.5-2.8)\end{array}$ & $\begin{array}{l}7.6(6.7-8.7) \\
7.3(6.3-8.7)\end{array}$ & $\begin{array}{c}0.93 \\
(0.75-1.15)\end{array}$ & $\begin{array}{c}1.05 \\
(0.86-1.27)\end{array}$ \\
\hline Cainap et al (2015) & $\begin{array}{l}\text { Linifanib } \\
\text { Sorafenib } \\
\text { Linifanib } \\
\text { Sorafenib }\end{array}$ & $\begin{array}{l}514 \\
521\end{array}$ & $1 \mathrm{st}$ & $\begin{array}{l}7 a \\
7 b\end{array}$ & $\begin{array}{l}\text { TTP } \\
\text { TTP } \\
\text { PFS } \\
\text { PFS }\end{array}$ & $\begin{array}{l}5.4(4.2-5.6) \\
4.0(2.8-4.2) \\
4.2(4.1-5.4) \\
2.9(2.8-4.0)\end{array}$ & $\begin{array}{l}9.1(8.1-10.2) \\
9.8(8.3-11.0) \\
9.1(8.1-10.2) \\
9.8(8.3-11.0)\end{array}$ & $\begin{array}{c}0.76 \\
(0.64-0.90) \\
0.813 \\
(0.697-0.948)\end{array}$ & $\begin{array}{c}1.05 \\
(0.90-1.22) \\
1.05 \\
(0.90-1.22)\end{array}$ \\
\hline Zhu et al (2015b) & $\begin{array}{l}\text { Sorafenib + Erlotinib } \\
\text { Sorafenib + Placebo }\end{array}$ & $\begin{array}{l}362 \\
358\end{array}$ & $1 \mathrm{st}$ & $\begin{array}{l}8 a \\
8 b\end{array}$ & $\begin{array}{l}\text { TTP } \\
\text { TTP }\end{array}$ & $\begin{array}{l}3.2 \\
4.0\end{array}$ & $\begin{array}{l}9.5 \\
8.5\end{array}$ & $\begin{array}{c}1.14 \\
(0.94-1.37)\end{array}$ & $\begin{array}{c}0.93 \\
(0.78-1.11)\end{array}$ \\
\hline Zhu et al (2015a) & $\begin{array}{l}\text { Ramucirumab } \\
\text { Placebo } \\
\text { Ramucirumab } \\
\text { Placebo }\end{array}$ & $\begin{array}{l}283 \\
282\end{array}$ & 2nd & $\begin{array}{l}9 a \\
9 b\end{array}$ & $\begin{array}{l}\text { TTP } \\
\text { TTP } \\
\text { PFS } \\
\text { PFS }\end{array}$ & $\begin{array}{l}3.5(2.8-4.5) \\
2.6(1.6-2.8) \\
2.8(2.7-3.9) \\
2.1(1.6-2.7)\end{array}$ & $\begin{array}{c}9.2(8.1-10.6) \\
7.6(6.0-9.3) \\
9.2(8.1-10.6) \\
7.6(6.0-9.3)\end{array}$ & $\begin{array}{c}0.59 \\
(0.49-0.72) \\
0.63 \\
(0.52-0.75)\end{array}$ & $\begin{array}{c}0.87 \\
(0.72-1.05) \\
0.87 \\
(0.72-1.05)\end{array}$ \\
\hline
\end{tabular}

Table 2. Baseline characteristics of included studies

\begin{tabular}{|c|c|c|c|c|c|c|c|c|c|c|c|c|c|c|c|}
\hline \multirow[b]{2}{*}{ References } & \multirow[b]{2}{*}{ Treatment arms } & \multirow[b]{2}{*}{$N$} & \multicolumn{3}{|c|}{ ECOG PS } & \multicolumn{4}{|c|}{ BCLC stage } & \multicolumn{3}{|c|}{ Child-Pugh score } & \multicolumn{3}{|c|}{ HCC aetiology } \\
\hline & & & 0 & 1 & 2 & A & B & C & D & A & B & C & HBV & $\mathrm{HCV}$ & Alcoholic \\
\hline Llovet et al (2008b) & $\begin{array}{l}\text { Sorafenib } \\
\text { Placebo }\end{array}$ & $\begin{array}{l}290 \\
303\end{array}$ & $\begin{array}{l}54 \% \\
54 \%\end{array}$ & $\begin{array}{l}38 \% \\
39 \%\end{array}$ & $\begin{array}{l}8 \% \\
7 \%\end{array}$ & $\begin{array}{l}0 \% \\
0 \%\end{array}$ & $\begin{array}{l}18 \% \\
17 \%\end{array}$ & $\begin{array}{l}82 \% \\
83 \%\end{array}$ & $\begin{array}{l}0 \% \\
0 \%\end{array}$ & $\begin{array}{l}95 \% \\
98 \%\end{array}$ & $\begin{array}{l}5 \% \\
2 \%\end{array}$ & $\begin{array}{l}0 \% \\
0 \%\end{array}$ & $\begin{array}{l}19 \% \\
18 \%\end{array}$ & $\begin{array}{l}29 \% \\
27 \%\end{array}$ & $\begin{array}{l}26 \% \\
26 \%\end{array}$ \\
\hline Cheng et al (2009) & $\begin{array}{l}\text { Sorafenib } \\
\text { Placebo }\end{array}$ & $\begin{array}{r}150 \\
76\end{array}$ & $\begin{array}{l}25 \% \\
28 \%\end{array}$ & $\begin{array}{l}69 \% \\
67 \%\end{array}$ & $\begin{array}{l}5 \% \\
5 \%\end{array}$ & $\begin{array}{l}\text { N/A } \\
\text { N/A }\end{array}$ & $\begin{array}{l}\text { N/A } \\
\text { N/A }\end{array}$ & $\begin{array}{l}95 \% \\
96 \%\end{array}$ & $\begin{array}{l}\text { N/A } \\
\text { N/A }\end{array}$ & $\begin{array}{l}97 \% \\
97 \%\end{array}$ & $\begin{array}{l}3 \% \\
3 \%\end{array}$ & $\begin{array}{l}0 \% \\
0 \%\end{array}$ & $\begin{array}{l}71 \% \\
78 \%\end{array}$ & $\begin{array}{r}11 \% \\
4 \%\end{array}$ & $\begin{array}{l}\text { N/A } \\
\text { N/A }\end{array}$ \\
\hline Llovet et al (2013) & $\begin{array}{l}\text { Brivanib } \\
\text { Placebo }\end{array}$ & $\begin{array}{l}263 \\
132\end{array}$ & $\begin{array}{l}57 \% \\
61 \%\end{array}$ & $\begin{array}{l}39 \% \\
35 \%\end{array}$ & $\begin{array}{l}4 \% \\
4 \%\end{array}$ & $\begin{array}{l}3 \% \\
1 \%\end{array}$ & $\begin{array}{r}9 \% \\
14 \%\end{array}$ & $\begin{array}{l}87 \% \\
85 \%\end{array}$ & $\begin{array}{l}1 \% \\
0 \%\end{array}$ & $\begin{array}{l}92 \% \\
91 \%\end{array}$ & $\begin{array}{l}7 \% \\
9 \%\end{array}$ & $\begin{array}{l}1 \% \\
0 \%\end{array}$ & $\begin{array}{l}39 \% \\
34 \%\end{array}$ & $\begin{array}{l}28 \% \\
27 \%\end{array}$ & $\begin{array}{l}23 \% \\
27 \%\end{array}$ \\
\hline Johnson et al (2013) & $\begin{array}{l}\text { Brivanib } \\
\text { Sorafenib }\end{array}$ & $\begin{array}{l}577 \\
578\end{array}$ & $\begin{array}{l}64 \% \\
61 \%\end{array}$ & $\begin{array}{l}36 \% \\
39 \%\end{array}$ & $\begin{array}{l}0 \% \\
0 \%\end{array}$ & $\begin{array}{l}6 \% \\
5 \%\end{array}$ & $\begin{array}{l}17 \% \\
17 \%\end{array}$ & $\begin{array}{l}77 \% \\
78 \%\end{array}$ & $\begin{array}{l}0 \% \\
0 \%\end{array}$ & $\begin{array}{l}92 \% \\
92 \%\end{array}$ & $\begin{array}{l}8 \% \\
8 \%\end{array}$ & $\begin{array}{l}0 \% \\
0 \%\end{array}$ & $\begin{array}{l}44 \% \\
45 \%\end{array}$ & $\begin{array}{l}20 \% \\
21 \%\end{array}$ & $\begin{array}{l}18 \% \\
14 \%\end{array}$ \\
\hline Cheng et al (2013) & $\begin{array}{l}\text { Sunitinib } \\
\text { Sorafenib }\end{array}$ & $\begin{array}{l}530 \\
544\end{array}$ & $\begin{array}{l}53 \% \\
53 \%\end{array}$ & $\begin{array}{l}47 \% \\
47 \%\end{array}$ & $\begin{array}{l}0 \% \\
0 \%\end{array}$ & $\begin{array}{l}0 \% \\
0 \%\end{array}$ & $\begin{array}{l}13 \% \\
16 \%\end{array}$ & $\begin{array}{l}87 \% \\
84 \%\end{array}$ & $\begin{array}{l}0 \% \\
0 \%\end{array}$ & $\begin{array}{l}100 \% \\
100 \%\end{array}$ & $\begin{array}{l}0 \% \\
0 \%\end{array}$ & $\begin{array}{l}0 \% \\
0 \%\end{array}$ & $\begin{array}{l}55 \% \\
53 \%\end{array}$ & $\begin{array}{l}21 \% \\
22 \%\end{array}$ & $\begin{array}{l}17 \% \\
15 \%\end{array}$ \\
\hline Zhu et al (2014) & $\begin{array}{l}\text { Everolimus } \\
\text { Placebo }\end{array}$ & $\begin{array}{l}362 \\
184\end{array}$ & $\begin{array}{l}59 \% \\
57 \%\end{array}$ & $\begin{array}{l}36 \% \\
40 \%\end{array}$ & $\begin{array}{l}5 \% \\
3 \%\end{array}$ & $\begin{array}{l}0 \% \\
0 \%\end{array}$ & $\begin{array}{l}14 \% \\
14 \%\end{array}$ & $\begin{array}{l}86 \% \\
86 \%\end{array}$ & $\begin{array}{l}0 \% \\
0 \%\end{array}$ & $\begin{array}{l}98 \% \\
99 \%\end{array}$ & $\begin{array}{l}2 \% \\
1 \%\end{array}$ & $\begin{array}{l}0 \% \\
0 \%\end{array}$ & $\begin{array}{l}25 \% \\
28 \%\end{array}$ & $\begin{array}{l}26 \% \\
23 \%\end{array}$ & $\begin{array}{l}18 \% \\
25 \%\end{array}$ \\
\hline Zhu et al (2015a) & $\begin{array}{l}\text { Ramucirumab } \\
\text { Placebo }\end{array}$ & $\begin{array}{l}283 \\
282\end{array}$ & $\begin{array}{l}56 \% \\
54 \%\end{array}$ & $\begin{array}{l}44 \% \\
46 \%\end{array}$ & $\begin{array}{l}0 \% \\
0 \%\end{array}$ & $\begin{array}{l}0 \% \\
0 \%\end{array}$ & $\begin{array}{l}12 \% \\
12 \%\end{array}$ & $\begin{array}{l}88 \% \\
88 \%\end{array}$ & $\begin{array}{l}0 \% \\
0 \%\end{array}$ & $\begin{array}{l}56 \% \\
54 \%\end{array}$ & $\begin{array}{l}44 \% \\
46 \%\end{array}$ & $\begin{array}{l}0 \% \\
0 \%\end{array}$ & $\begin{array}{l}35 \% \\
36 \%\end{array}$ & $\begin{array}{l}27 \% \\
27 \%\end{array}$ & $\begin{array}{l}\text { N/A } \\
\text { N/A }\end{array}$ \\
\hline
\end{tabular}

0.87 (95\% CI $0.19-0.99, P=0.022$ ), respectively, for first line and second line setting. Corresponding $R^{2}$ value was $0.28(95 \% \mathrm{CI}$ $0-0.58, \quad P=0.075)$ and $0.80(95 \%$ CI $0.06-0.90, \quad P=0.016)$, respectively.

$\mathbf{H R}_{\mathrm{TTP}}$ as a surrogate marker for $\mathbf{H R}_{\mathrm{OS}}$. To evaluate whether the reduction in HR of TTP by a specific treatment can predict its reduction in $\mathrm{HR}$ of OS, we analysed the association between $\mathrm{HR}_{\mathrm{TTP}}$ and $\mathrm{HR}_{\mathrm{OS}}$. In six studies, which compared the efficacy of drug vs placebo, placebo was used as a control arm. In three studies, which compared the efficacy of novel molecular targeted agent with sorafenib, sorafenib was defined as a control arm. The $r_{\mathrm{s}}$ value between $\log \left(\mathrm{HR}_{\mathrm{TTP}}\right)$ and $\log \left(\mathrm{HR}_{\mathrm{OS}}\right)$ was 0.73 (95\% CI 0.12-0.94, $P=0.024$; Figure 2). The corresponding $R^{2}$ was 0.57 (95\% CI $0.02-$ $0.77, P=0.018)$ and the regression equation was $\log \left(\mathrm{HR}_{\mathrm{OS}}\right)=0.08$ $+0.52 \log \left(\mathrm{HR}_{\mathrm{TTP}}\right)$ indicating that the $10 \%$ risk reduction in TTP 


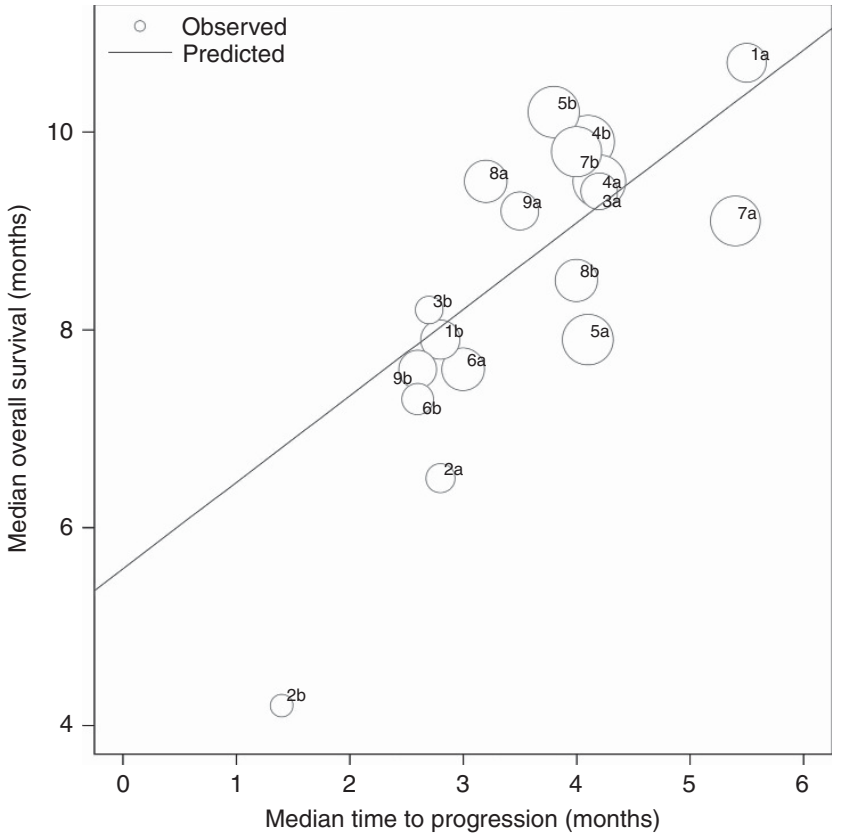

Figure 1. Correlation between median TTP and median OS. Circle size is proportional to the number of randomised patients in each arm. The linear equation was median $O S=5.59+0.87$ median TTP $\left(R^{2}=0.42, P=0.004\right)$. Abbreviations: TTP, time to progression; OS, overall survival.

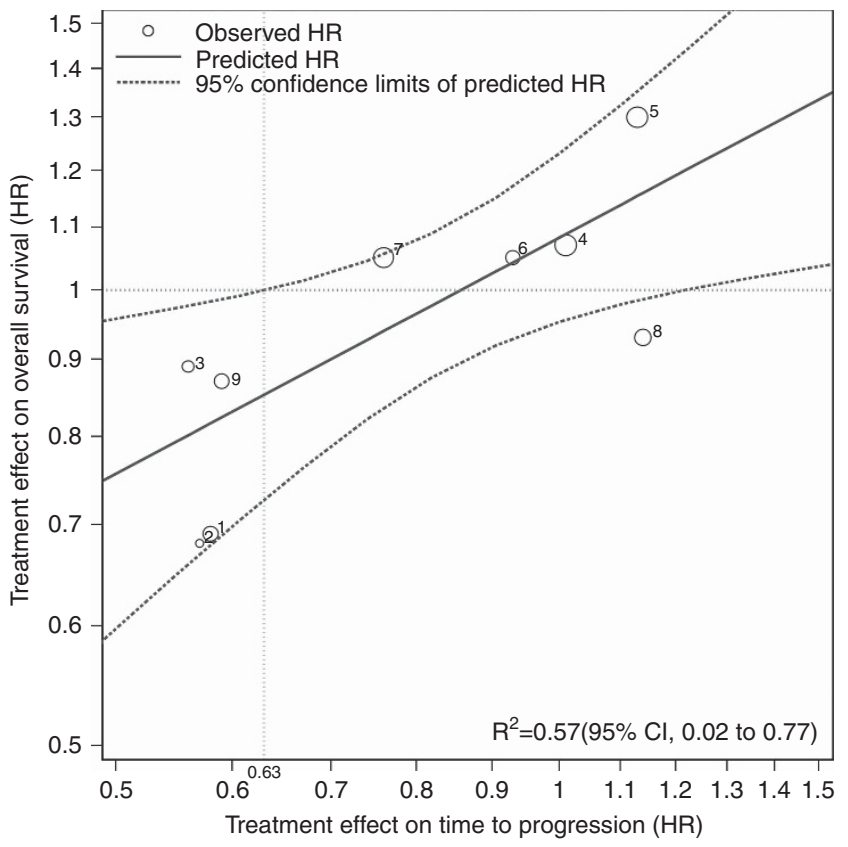

Figure 2. Correlation between treatment effects of TTP and OS. Treatment effects were logarithms of hazard ratios of TTP and OS in each study. Circle size is proportional to the total number of randomised patients in each study. Log scale was used for the $x$ axis and $y$ axis. The linear equation was $\log \mathrm{HR}_{\mathrm{OS}}=0.080+0.52 \log \mathrm{HR}_{\mathrm{TTP}}$ $\left(R^{2}=0.57, P=0.018\right)$. The vertical line represents the minimum TTP effect to predict a treatment effect on OS. Abbreviations: HR, hazard ratio; OS, overall survival; TTP, time to progression.

would yield 5.2\% OS risk reduction as reflected in the slope of 0.52 . The minimum TTP effect to predict a treatment effect on OS was 0.63 , derived from a vertical line that transects the upper $95 \% \mathrm{CI}$ and an OS of HR equal to 1 .

\section{DISCUSSION}

Although OS is the gold standard survival endpoint in the clinical trial, it can be affected by sequential treatment after progression and by crossover from control to experimental arms. In addition, OS requires longer follow-up duration. Using surrogate markers such as TTP and PFS can overcome these problems. PFS is defined as the time from randomisation to documented progression or death from any cause. Although PFS is suggested as a reliable surrogate endpoint in many solid tumours, using PFS as a surrogate marker in HCC might confound treatment outcome as $60-80 \%$ of patients with HCC have underling liver cirrhosis and many HCC patients die from the progression of liver failure (Volk and Marrero, 2008). TTP, which death before progression is censored as non-progression, has been suggested as reliable surrogate endpoints in HCC (Llovet et al, 2008a). However, the correlation between TTP and OS has never been evaluated. In the present study, we have investigated that TTP could serve as a surrogate marker for OS based on a relationship between $\mathrm{HR}_{\mathrm{TTP}}$ and $\mathrm{HR}_{\mathrm{OS}}$ in 9 phase III studies of advanced HCC. In addition, median TTP was associated with median OS.

The correlation of surrogate endpoints and OS can be influenced by sequential treatment after progression. In a subgroup analysis, the $r_{\mathrm{s}}$ value and $R^{2}$ value between TTP and OS in the first line studies were $0.59(P=0.043)$ and 0.28 $(P=0.075)$. In the second line studies, $r_{\mathrm{s}}$ value and $R^{2}$ value between TTP and OS were $0.87(P=0.022)$ and $0.80(P=0.016)$. The correlation between TTP and OS was higher in the second line setting compared with the first line setting. This could be expected as patients enroled in the first line therapy have a higher chance to receive additional treatment after progression compared with those enroled in the second line therapy. In addition, although there is no effective second line systemic chemotherapy besides regorafenib, which has recently been reported, this result may indicate that the survival of HCC patients treated with molecular targeted agent can be influenced by following local therapy or supportive care. However, we could not perform subgroup analysis using HR due to limited number of study included in the study. Although analysis of median data uses each treatment arm as a variates, paired treatment arm is needed in the analysis of HR. Thus, we cannot confirm that the correlation between TTP and OS is higher in the second line setting compared with the first line setting.

There are several limitations in the present study. A reliable surrogate endpoint should be associated with outcome in both individual-level and trial-level measure (Buyse et al, 2000a). This study was a meta-analysis of previous studies and the association of surrogate endpoint and OS was done in trial-level measure but not in individual-level. Analyses of patient-level data are needed to confirm the surrogacy of TTP for OS. Another limitation of the present study is that only nine clinical trials were included in the meta-analysis. Six studies were performed in first line population and only three studies evaluated second line treatment population. However, our meta-analysis included all randomised controlled phase III trials evaluating the role of molecular targeted therapy in advanced HCC, which have been reported since the advent of sorafenib. In addition, this is the first meta-analysis to evaluate the association of TTP and OS in advanced HCC.

In conclusion, TTP could be used as a surrogate marker in advanced HCC patients treated with molecular targeted therapy. However, the results suggest modest correlation between treatment effects on TTP and OS. Along with individual-level analysis, additional work is needed to confirm our findings. 


\section{ACKNOWLEDGEMENTS}

This study was supported in part by Grant No. 23-2015-0110 from the SNUH Research Fund, and by a grant of the Korea Health Technology R\&D Project through the Korea Health Industry Development Institute (KHIDI), funded by the Ministry of Health \& Welfare, Republic of Korea (Grant Number: HI14C1277).

\section{CONFLICT OF INTEREST}

The authors declare no conflict of interest.

\section{REFERENCES}

Blumenthal GM, Karuri SW, Zhang H, Zhang L, Khozin S, Kazandjian D, Tang S, Sridhara R, Keegan P, Pazdur R (2015) Overall response rate, progression-free survival, and overall survival with targeted and standard therapies in advanced non-small-cell lung cancer: US Food and Drug Administration trial-level and patient-level analyses. J Clin Oncol 33(9): 1008-1014.

Bosch FX, Ribes J, Borras J (1999) Epidemiology of primary liver cancer. Semin Liver Dis 19(3): 271-285.

Bruix J, Merle P, Granito A, Huang Y-H, Bodoky G, Yokosuka O, Rosmorduc O, Breder V, Gerolami R, Masi G, Ross Paul J, Qin S, Song T, Bronowicki J-P, Ollivier-Hourmand I, Kudo M, LeBerre M-A, Baumhauer A, Meinhardt G, Han G (2016) LBA-03Efficacy and safety of regorafenib versus placebo in patients with hepatocellular carcinoma (HCC) progressing on sorafenib: results of the international, randomized phase 3 RESORCE trial. Ann Oncol 27(suppl 2): iil40-ii141.

Buyse M (2009) Use of meta-analysis for the validation of surrogate endpoints and biomarkers in cancer trials. Cancer J 15(5): 421-425.

Buyse M, Burzykowski T, Carroll K, Michiels S, Sargent DJ, Miller LL, Elfring GL, Pignon JP, Piedbois P (2007) Progression-free survival is a surrogate for survival in advanced colorectal cancer. J Clin Oncol 25(33): 5218-5224.

Buyse M, Molenberghs G, Burzykowski T, Renard D, Geys H (2000a) The validation of surrogate endpoints in meta-analyses of randomized experiments. Biostatistics 1(1): 49-67.

Buyse M, Thirion P, Carlson RW, Burzykowski T, Molenberghs G, Piedbois P (2000b) Relation between tumour response to first-line chemotherapy and survival in advanced colorectal cancer: a meta-analysis. Meta-Analysis Group in Cancer. Lancet 356(9227): 373-378.

Cainap C, Qin S, Huang WT, Chung IJ, Pan H, Cheng Y, Kudo M, Kang YK, Chen PJ, Toh HC, Gorbunova V, Eskens FA, Qian J, McKee MD, Ricker JL, Carlson DM, El-Nowiem S (2015) Linifanib versus sorafenib in patients with advanced hepatocellular carcinoma: results of a randomized phase III trial. J Clin Oncol 33(2): 172-179.

Cheng AL, Kang YK, Chen Z, Tsao CJ, Qin S, Kim JS, Luo R, Feng J, Ye S, Yang TS, Xu J, Sun Y, Liang H, Liu J, Wang J, Tak WY, Pan H, Burock K, Zou J, Voliotis D, Guan Z (2009) Efficacy and safety of sorafenib in patients in the Asia-Pacific region with advanced hepatocellular carcinoma: a phase III randomised, double-blind, placebo-controlled trial. Lancet Oncol 10(1): 25-34.

Cheng AL, Kang YK, Lin DY, Park JW, Kudo M, Qin S, Chung HC, Song X, Xu J, Poggi G, Omata M, Pitman Lowenthal S, Lanzalone S, Yang L, Lechuga MJ, Raymond E (2013) Sunitinib versus sorafenib in advanced hepatocellular cancer: results of a randomized phase III trial. J Clin Oncol 31(32): 4067-4075.

Fattovich G, Stroffolini T, Zagni I, Donato F (2004) Hepatocellular carcinoma in cirrhosis: incidence and risk factors. Gastroenterology 127(5 Suppl 1): S35-S50.

Johnson PJ, Qin S, Park JW, Poon RT, Raoul JL, Philip PA, Hsu CH, Hu TH, Heo J, Xu J, Lu L, Chao Y, Boucher E, Han KH, Paik SW, Robles-Avina J, Kudo M, Yan L, Sobhonslidsuk A, Komov D, Decaens T, Tak WY, Jeng LB, Liu D, Ezzeddine R, Walters I, Cheng AL (2013) Brivanib versus sorafenib as first-line therapy in patients with unresectable, advanced hepatocellular carcinoma: results from the randomized phase III BRISK-FL study. J Clin Oncol 31(28): 3517-3524.

Llovet JM, Decaens T, Raoul JL, Boucher E, Kudo M, Chang C, Kang YK, Assenat E, Lim HY, Boige V, Mathurin P, Fartoux L, Lin DY, Bruix J, Poon RT, Sherman M, Blanc JF, Finn RS, Tak WY, Chao Y, Ezzeddine R, Liu D, Walters I, Park JW (2013) Brivanib in patients with advanced hepatocellular carcinoma who were intolerant to sorafenib or for whom sorafenib failed: results from the randomized phase III BRISK-PS study. J Clin Oncol 31(28): 3509-3516.

Llovet JM, Di Bisceglie AM, Bruix J, Kramer BS, Lencioni R, Zhu AX, Sherman M, Schwartz M, Lotze M, Talwalkar J, Gores GJ (2008a) Design and endpoints of clinical trials in hepatocellular carcinoma. J Natl Cancer Inst 100(10): 698-711.

Llovet JM, Ricci S, Mazzaferro V, Hilgard P, Gane E, Blanc JF, de Oliveira AC, Santoro A, Raoul JL, Forner A, Schwartz M, Porta C, Zeuzem S, Bolondi L, Greten TF, Galle PR, Seitz JF, Borbath I, Haussinger D, Giannaris T, Shan M, Moscovici M, Voliotis D, Bruix J (2008b) Sorafenib in advanced hepatocellular carcinoma. N Engl J Med 359(4): 378-390.

Ozer-Stillman I, Strand L, Chang J, Mohamed AF, Tranbarger-Freier KE (2015) Meta-analysis for the association between overall survival and progression-free survival in gastrointestinal stromal tumour. Clin Cancer Res 21(2): 295-302.

Petrelli F, Barni S (2014) Surrogate endpoints in metastatic breast cancer treated with targeted therapies: an analysis of the first-line phase III trials. Med Oncol 31(1): 776.

Sargent DJ, Wieand HS, Haller DG, Gray R, Benedetti JK, Buyse M, Labianca R, Seitz JF, O'Callaghan CJ, Francini G, Grothey A, O'Connell M, Catalano PJ, Blanke CD, Kerr D, Green E, Wolmark N, Andre T, Goldberg RM, De Gramont A (2005) Disease-free survival versus overall survival as a primary end point for adjuvant colon cancer studies: individual patient data from 20898 patients on 18 randomized trials. J Clin Oncol 23(34): 8664-8670.

Thomas MB, Jaffe D, Choti MM, Belghiti J, Curley S, Fong Y, Gores G, Kerlan R, Merle P, O’Neil B, Poon R, Schwartz L, Tepper J, Yao F, Haller D, Mooney M, Venook A (2010) Hepatocellular carcinoma: consensus recommendations of the National Cancer Institute Clinical Trials Planning Meeting. J Clin Oncol 28(25): 3994-4005.

Torre LA, Bray F, Siegel RL, Ferlay J, Lortet-Tieulent J, Jemal A (2015) Global cancer statistics, 2012. CA Cancer J Clin 65(2): 87-108.

Volk ML, Marrero JA (2008) Early detection of liver cancer: diagnosis and management. Curr Gastroenterol Rep 10(1): 60-66.

Zhu AX (2006) Systemic therapy of advanced hepatocellular carcinoma: how hopeful should we be? Oncologist 11(7): 790-800.

Zhu AX, Kudo M, Assenat E, Cattan S, Kang YK, Lim HY, Poon RT, Blanc JF, Vogel A, Chen CL, Dorval E, Peck-Radosavljevic M, Santoro A, Daniele B, Furuse J, Jappe A, Perraud K, Anak O, Sellami DB, Chen LT (2014) Effect of everolimus on survival in advanced hepatocellular carcinoma after failure of sorafenib: the EVOLVE-1 randomized clinical trial. JAMA 312(1): 57-67.

Zhu AX, Park JO, Ryoo BY, Yen CJ, Poon R, Pastorelli D, Blanc JF, Chung HC, Baron AD, Pfiffer TE, Okusaka T, Kubackova K, Trojan J, Sastre J, Chau I, Chang SC, Abada PB, Yang L, Schwartz JD, Kudo M (2015a) Ramucirumab versus placebo as second-line treatment in patients with advanced hepatocellular carcinoma following first-line therapy with sorafenib $(\mathrm{REACH})$ : a randomised, double-blind, multicentre, phase 3 trial. Lancet Oncol 16(7): 859-870.

Zhu AX, Rosmorduc O, Evans TR, Ross PJ, Santoro A, Carrilho FJ, Bruix J, Qin S, Thuluvath PJ, Llovet JM, Leberre MA, Jensen M, Meinhardt G, Kang YK (2015b) SEARCH: a phase III, randomized, double-blind, placebo-controlled trial of sorafenib plus erlotinib in patients with advanced hepatocellular carcinoma. J Clin Oncol 33(6): 559-566.

This work is published under the standard license to publish agreement. After 12 months the work will become freely available and the license terms will switch to a Creative Commons AttributionNonCommercial-Share Alike 4.0 Unported License. 